\title{
Multiple Linear Regression Analysis of the Seasonal Changes in the Serum Concentration of $\boldsymbol{\beta}$-Cryptoxanthin
}

\author{
Minoru Sugiura ${ }^{1, *}$, Hikaru MATSUmoto ${ }^{1}$, Masaya KATO $^{1}$, Yoshinori IKOMA ${ }^{1}$, \\ Masamichi YANO ${ }^{1}$ and Akihiko NAGAO ${ }^{2}$ \\ ${ }^{1}$ Department of Citrus Research, National Institute of Fruit Tree Science, 485-6 Shimizu-Okitsunakachou, \\ Shizuoka-shi, Shizuoka 424-0292, Japan \\ ${ }^{2}$ Food Materials Research Division, National Food Research Institute, 2-1-12 Kannondai, Tsukuba-shi, \\ Ibaraki 305-8642, Japan
}

(Received November 8, 2003)

\begin{abstract}
Summary Beta-cryptoxanthin ( $\beta$-CRX) is a carotenoid pigment found in Satsuma mandarin (Citrus unshiu Marc.) fruit, which is heavily produced in Japan. In this study, we evaluated the seasonal changes in the serum $\beta$-CRX.level and investigated predictors of serum $\beta$-CRX level by multiple linear regression analysis. Blood tests and self-administered questionnaires were used every other month for one year. The subjects were healthy volunteers, 15 males and 12 females. The serum $\beta$-CRX levels increased dramatically as the intake of Satsuma mandarin increased; the maximum increase was noted in January. Multiple linear regression analysis showed that, in males, the serum $\beta$-CRX level could be predicted by Satsuma mandarin intake, age and the month of blood sampling; however, it was inversely associated with alcohol and smoking habits. Conversely, in females, the serum $\beta$-CRX concentration could be predicted by Satsuma mandarin intake, the month of blood sampling and age; however, it was inversely associated with body mass index. The results of multiple linear regression analysis suggest that the serum $\beta$-CRX levels can be used to evaluate the intake volume of Satsuma mandarin. Furthermore, $\beta$-CRX is a useful biomarker to estimate the beneficial effects of Satsuma mandarin intake in epidemiological studies.
\end{abstract}

Key Words serum, $\beta$-cryptoxanthin, Satsuma mandarin, multiple regression analysis, seasonal change

Recent epidemiological studies and animal experiments provide strong support for the hypothesis that the daily intake of fruits and vegetables is effective in the prevention of diseases such as cancer, coronary heart disease, diabetes and hypercholesterolemia (1-6). Furthermore, reports of recent epidemiological studies have shown that the serum concentration of carotenoids or vitamins is well correlated with the intake of fruits and vegetables (7-12). These findings are associated with numerous case-control or prospective cohort studies showing the relationship of the intake of fruits and vegetables with chronic diseases such as cancer or cardiovascular disease, using biomarkers ( $\beta$-carotene, lycopene, ascorbic acid and $\alpha$-tocopherol) that reflect the intake frequency of fruits and vegetables (13-20). However, the above biomarkers cannot be used to estimate the intake volume of specific foods because carotenoids and vitamins are abundant in fruits and vegetables (21-24).

Satsuma mandarin is a major crop in Japan. Previously, we discovered that the serum concentration of $\beta$ cryptoxanthin ( $\beta$-CRX), which is abundant in Satsuma mandarin, increases in proportion to the intake of Satsuma mandarin and is a useful biomarker for esti-

\footnotetext{
*To whom correspondence should be addressed.

E-mail: msugiura@affrc.go.jp
}

mating the intake frequency of Satsuma mandarin (25). These findings make it possible to evaluate the beneficial effects of Satsuma mandarin by measuring the serum $\beta$-CRX level, which can be used as a useful biomarker that reflects the intake frequency of Satsuma mandarin with a good degree of accuracy. However, as mentioned in our previous report, the serum $\beta$-CRX level was examined only twice in one year, and details of the seasonal changes of the serum $\beta$-CRX level were not clarified. Furthermore, the dependent variables that influence serum $\beta$-CRX levels, any except for Satsuma mandarin intake, were not identified.

In this study, we evaluated the seasonal changes in the serum $\beta$-CRX and investigated the predictors of serum $\beta$-CRX by multiple linear regression analysis.

\section{SUBJECTS AND METHODS}

Subject. The subjects included 15 male and 12 female healthy volunteers, from 36 to $67 \mathrm{y}$ of age (median, $57 \mathrm{y}$; SD, 8.37). They were rural residents of Shizuoka Prefecture in Japan. Volunteers were given written information about the study, and informed consent was obtained from each participant. The subjects lived at home, and they consumed their usual diets. None of the subjects took medications, vitamins or mineral supplements.

Study design. The volunteers completed self-admin- 
istered questionnaires seeking information about the intake frequency of Satsuma mandarin and other fruits and vegetables. The subjects were asked about their intake frequency of Satsuma mandarin and the number consumed in the three days before the blood test. They were also asked about their intake frequency of other food in the three days before the blood test. Specific attention was given to the consumption of fruits and vegetables that contain $\beta$-CRX, such as apricot, chili, loquat, orange, peach, pepper, papaya, and related processed foods, including juice or canned foods, in the light of previous reports concerning carotenoid contents in foods (21-24). Furthermore, participants were asked about their daily habits. They assessed their alcohol intake by indicating one of the following categories: non-drinker; occasional drinker; 1-2 drinks weekly; 35 drinks weekly; almost daily drinker. Smoking habits were also categorized as follows: non-smoker; exsmoker; 1-10 cigarettes daily; 11-20 cigarettes daily; $>20$ cigarettes daily. Participants were asked to maintain their regular lifestyle during the survey. Blood test and self-administered questionnaires were used every other month for one year, from September 2002 to July 2003.

This survey was carried out following examination by the Ethics Committee of the National Institute of Fruit Tree Science.

Blood analysis. Fasting blood samples were collected. After clotting for $30 \mathrm{~min}$ in the dark at room temperature, the blood samples were centrifuged for $10 \mathrm{~min}$ at $1,800 \mathrm{~g}$ to obtain serum. After the serum was removed, total cholesterol, triacylglycerols, HDL cholesterol and LDL cholesterol were immediately measured. The serum total cholesterol, triacylglycerols, HDL cho- lesterol and LDL cholesterol of each individual were measured by enzymatic photometric methods using commercial kits (Kyowa-Medics, Inc., Tokyo, Japan). Serum samples were stored at $-80^{\circ} \mathrm{C}$ until $\beta$-CRX analysis. The concentration of serum $\beta$-CRX was analyzed by reverse-phase high-performance liquid chromatography using $\beta$-apo- 8 '-carotenal as the internal standard. Serum sample was mixed with $\mathrm{H}_{2} \mathrm{O}$ and ethanol containing $\beta$-apo- 8 '-carotenal and extracted into hexane. The organic layer was removed, evaporated to dryness at room temperature, resolved in chloroform: ethanol $(1: 19)$ and transferred to microvial for automatic injection. The HPLC system was a Model HP1100 (Hewlett-Packard, Toronto, Canada) fitted with a 201TP54 reverse-phase C18 column (Grace/Vydac, CA, USA). Beta-CRX was monitored at $480 \mathrm{~nm}$ on the HPLC system. The mobile phase component was methanol: tetrahydrofuran: $\mathrm{H}_{2} \mathrm{O}(94: 5: 1)$ and the flow rate of the phase was $0.8 \mathrm{~mL} / \mathrm{min}$. The peak of $\beta$-CRX was identified by retention time and quantified using standard curves of authentic $\beta$-CRX (FUNAKOSHI, Tokyo, Japan).

Statistical analysis. The statistical analysis was performed using the SPSS version $11.0 \mathrm{~J}$ (SPSS Inc., Illinois, USA). We developed multiple linear regression models to evaluate dietary food and lifestyle predictors of serum $\beta$-CRX levels. As independent variables, sex, age, body mass index, tobacco and alcohol intake, and frequency of the intake of foods containing $\beta$-CRX were calculated by multiple linear stepwise regression analysis. Because the month that blood was sampled was one determinant of the serum $\beta$-CRX level, the month with the lowest average serum $\beta$-CRX level was used as the reference (fixed) month. The period of blood sampling,

Table 1. Characteristic of study subjects by sex.

\begin{tabular}{lrr}
\hline \multicolumn{1}{c}{ Characteristics } & Male $(n=15)$ & Female $(n=12)$ \\
\hline Age (year) & $59.27(6.26)^{\mathrm{a}}$ & $51.33(8.87)^{\mathrm{a}}$ \\
Body mass index $\left(\mathrm{kg} / \mathrm{m}^{2}\right)$ & $23.04(2.09)^{\mathrm{a}}$ & $22.17(2.40)^{\mathrm{a}}$ \\
Total cholesterol $(\mathrm{mg} / \mathrm{dL})$ & $208.27(22.18)^{\mathrm{a}}$ & $216.92(41.64)^{\mathrm{a}}$ \\
Triacylglycerols $(\mathrm{mg} / \mathrm{dL})$ & $115.40(79.47)^{\mathrm{a}}$ & $85.67(31.78)^{\mathrm{a}}$ \\
HDL cholesterol (mg/dL) & $60.22(19.76)^{\mathrm{a}}$ & $112.33(27.19)^{\mathrm{a}}$ \\
LDL cholesterol $(\mathrm{mg} / \mathrm{dL})$ & $105.67(12.36)^{\mathrm{a}}$ & $10^{\mathrm{b}}$ \\
\hline Smoking habit & & $2^{\mathrm{b}}$ \\
Non-smokers & $8^{\mathrm{b}}$ & $0^{\mathrm{b}}$ \\
Ex-smokers & $6^{\mathrm{b}}$ & $0^{\mathrm{b}}$ \\
Current smokers (cigarette/d) & & $0^{\mathrm{b}}$ \\
10< & $0^{\mathrm{b}}$ & $8^{\mathrm{b}}$ \\
10-20 & $0^{\mathrm{b}}$ & $1^{\mathrm{b}}$ \\
20> & $1^{\mathrm{b}}$ & $1^{\mathrm{b}}$
\end{tabular}

${ }^{\mathrm{a}}$ all data are represented as mean and standard deviation in parenthesis; ${ }^{\mathrm{b}}$ number of obsevations. 
designated by the month, was categorized using a score of one to six according to the average serum $\beta$-CRX level in one year. The significance was accepted when the null hypothesis was rejected at the $p<0.05$ level.

\section{RESULTS}

Self-administered questionnaires and blood tests were obtained from all 27 participants at each scheduled test. The characteristics of the study subjects by sex are shown in Table 1. The averages of age, body mass index, total cholesterol, triacylglycerols, HDL cholesterol and LDL cholesterol measured in September 2002 were summarized. The means of these parameters in all subjects did not change statistically during the study period (data not shown). The participants did not alter
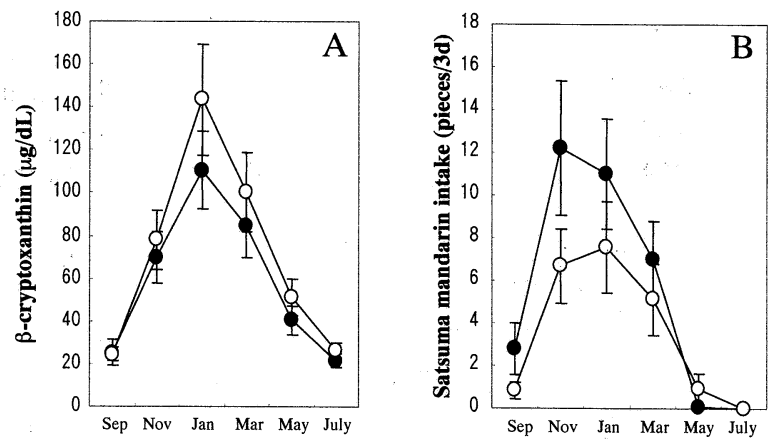

Fig. 1. Seasonal changes of serum $\beta$-cryptoxanthin level and consumption frequency of Satsuma mandarin A: Seasonal changes of serum $\beta$-cryptoxanthin level. Closed circles show the results in males; open circles show those in females. B: Seasonal changes of Satsuma mandarin consumption volume in the three days before the blood test. Closed circles show the results in males, while open circles show those in females. All data are represented as means \pm S.E.M. Fifteen males and 12 females were volunteered for the survey. their normal habits during the survey period.

As shown in Fig. 1, the months with the lowest serum $\beta$-CRX levels were July and September for males and females, respectively. The serum $\beta$-CRX levels were at their highest in January for both sexes. The serum $\beta$ CRX levels in females were higher than those in males, but the differences were not statistically significant. The intake volume of Satsuma mandarin for $3 \mathrm{~d}$ before each blood test decreased in May and then increased dramatically in November. In July, none of the participants ate Satsuma mandarin. The intake volumes of Satsuma mandarin in males in September, November, January and March were higher than those in females, but these differences were not statistically significant.

Table 2 shows the Pearson correlation coefficients between serum $\beta$-CRX levels and intake volumes of Satsuma mandarin with variables from all data for the one-year period. Serum $\beta$-CRX levels in both males and females were strongly correlated with Satsuma mandarin intake in the month of blood sampling. Furthermore, serum $\beta$-CRX levels were also correlated with Satsuma mandarin intake 2 mo prior, but these correlations slightly diminished. The serum $\beta$-CRX levels were also well correlated with age in both males and females. In males, alcohol intake was negatively correlated with serum $\beta$-CRX levels and intake volume of Satsuma mandarin. On the other hand, in females, tobacco use was negatively correlated with serum $\beta$-CRX levels and Satsuma mandarin intake. Except for Satsuma mandarin, the frequency of consumption of fruits and vegetables and related processed food, including juice or canned foods that contain $\beta$-CRX, were not statistically correlated with serum $\beta$-CRX levels.

We developed multiple linear regression models to evaluate the predictors of serum $\beta$-CRX levels. The results of multiple linear regression analysis are shown in Table 3. As the independent variables, sex, age, body

Table 2. Pearson correlation coefficients between serum $\beta$-cryptoxanthin level and Satsuma mandarin intake with variables from all data for one-year period.

\begin{tabular}{|c|c|c|c|c|}
\hline \multirow{3}{*}{ Variables } & \multicolumn{4}{|c|}{ Pearson Correlation coefficients } \\
\hline & \multicolumn{2}{|c|}{ Male $\left(n=90^{\mathrm{a}}\right)$} & \multicolumn{2}{|c|}{ Female $\left(n=72^{b}\right)$} \\
\hline & $\beta$-CRX & Satsuma mandarin $^{\mathrm{c}}$ & $\beta$-CRX & Satsuma mandarin ${ }^{c}$ \\
\hline Age & $0.379^{* * *}$ & $0.370^{* * *}$ & $0.443^{* * *}$ & $0.481^{* *}$ \\
\hline Body mass index $\left(\mathrm{kg} / \mathrm{m}^{2}\right)$ & 0.034 & -0.082 & 0.051 & 0.253 \\
\hline Alcohol habit (category; 1-5) & $-0.290^{* *}$ & $-0.244^{*}$ & 0.029 & 0.021 \\
\hline Smoking habit (category; 1-5) & -0.155 & -0.001 & $-0.301^{*}$ & $-0.352^{* *}$ \\
\hline \multicolumn{5}{|c|}{ Satsuma mandarin consumption (pieces/3 d) } \\
\hline month of blood sampling & $0.723^{* * *}$ & - & $0.805^{* * *}$ & - \\
\hline two months ago & $0.700^{* * *}$ & $0.557^{* * *}$ & $0.688^{* * *}$ & $0.457^{* * *}$ \\
\hline Other fruits (times/3 d) & 0.213 & $0.264^{*}$ & 0.195 & 0.170 \\
\hline Mandarin juice (times/3 d) & 0.159 & -0.156 & -0.182 & -0.178 \\
\hline Green-yellow vegetables (times/3 d) & 0.138 & 0.033 & 0.165 & -0.086 \\
\hline Other vegetables (times/3 d) & -0.012 & 0.065 & 0.153 & -0.024 \\
\hline
\end{tabular}

${ }^{a}$ Number of 15 male observations $\times 6$ times; ${ }^{b}$ Number of 12 female observations $\times 6$ times; ${ }^{c}$ Satsuma mandarin consumption (pieces/3 d) at the month of blood sampling; Significance value ${ }^{*} p<0.05 ;{ }^{* *} p<0.01 ;{ }^{* * *} p<0.001$ 
Table 3. Multiple linear regression analysis of $\operatorname{serum} \beta$-cryptoxanthin with independent variables.

\begin{tabular}{|c|c|c|c|c|}
\hline Gender specific model & $R^{2}$ & Independent variables & $\begin{array}{l}\text { Standard regression } \\
\text { coefficient }\end{array}$ & $p$ value \\
\hline Male and Female & 0.735 & $\begin{array}{l}\text { Satsuma mandarin (pieces/3 d) } \\
\text { month of blood sampling } \\
\text { two months ago } \\
\text { Month of blood sampling (score; } 1-6) \\
\text { Age (y) } \\
\text { Sex }(1 \text { or } 2 \text { ) } \\
\text { Alcohol habit (category; } 1-5) \\
\text { Smoking habit (category; } 1-5)\end{array}$ & $\begin{array}{r}0.317 \\
0.194 \\
0.308 \\
0.371 \\
0.270 \\
-0.152 \\
-0.151\end{array}$ & $\begin{array}{l}p<0.001 \\
p=0.006 \\
p<0.001 \\
p<0.001 \\
p<0.001 \\
p=0.031 \\
p=0.008\end{array}$ \\
\hline Male & 0.752 & $\begin{array}{l}\text { Satsuma mandarin (pieces/3 d) } \\
\text { month of blood sampling } \\
\text { two months ago } \\
\text { Month of blood sampling (score; } 1-6 \text { ) } \\
\text { Age (y) } \\
\text { Alcohol habit (category; } 1-5 \text { ) } \\
\text { Smoking habit (category; } 1-5 \text { ) }\end{array}$ & $\begin{array}{r}0.313 \\
0.168 \\
0.289 \\
0.353 \\
-0.253 \\
-0.208\end{array}$ & $\begin{array}{l}p<0.001 \\
p=0.077 \\
p<0.001 \\
p<0.001 \\
p=0.002 \\
p=0.004\end{array}$ \\
\hline Female & 0.832 & $\begin{array}{l}\text { Satsuma mandarin (pieces/3 d) } \\
\text { month of blood sampling } \\
\text { two months ago } \\
\text { Month of blood sampling (score; } 1-6) \\
\text { Age }(y) \\
\text { Body mass index }\left(\mathrm{kg} / \mathrm{m}^{2}\right)\end{array}$ & $\begin{array}{r}0.448 \\
0.299 \\
0.273 \\
0.255 \\
-0.153\end{array}$ & $\begin{array}{l}p<0.001 \\
p<0.001 \\
p<0.001 \\
p=0.011 \\
p=0.044\end{array}$ \\
\hline
\end{tabular}

mass index, serum total cholesterol level, tobacco and alcohol intake, and the intake of foods that contain $\beta$ CRX were calculated by multiple linear stepwise regression analysis. Because the month that blood was sampled was one determinant of the serum $\beta$-CRX level, the month with the lowest average serum $\beta$-CRX level was used as the reference (fixed) month. The month in which blood was sampled was scored according to the mean value of the serum $\beta$-CRX level for the 15 males. They were as follows: Score 1: July; Score 2: September; Score 3: May; Score 4: November; Score 5: March; and Score 6: January. For females, the month in which blood was sampled was scored as follows: Score 1: September; Score 2: July; Score 3: May; Score 4: November; Score 5: March; and Score 6: January. As shown in Table 3, the serum $\beta$-CRX concentration was predicted by Satsuma mandarin intake at the month of blood sampling, Satsuma mandarin intake 2 mo prior, the month of blood sampling, age and sex; however, it was inversely associated with alcohol intake and smoking habit in the model for both sexes. In the gender-specific male model, the serum $\beta$-CRX concentration was predicted by Satsuma mandarin intake in the month of blood sampling, Satsuma mandarin intake 2 mo prior, the month of blood sampling, and age; however, it was inversely associated with alcohol intake and smoking habit. On the other hand, in the gender-specific female model, the serum $\beta$-CRX concentration was predicted by Satsuma mandarin intake in the month of blood sampling, Satsuma mandarin intake 2 mo prior, the month of blood sampling, and age; however, it was inversely associated with body mass index.

\section{DISCUSSION}

Our survey was conducted using volunteers who are residents in an area where Satsuma mandarin is popular. Previously, we discovered that the serum concentration of $\beta$-CRX increases in proportion to the intake of Satsuma mandarin and is a useful biomarker for estimating the intake frequency of Satsuma mandarin (25). These findings make it possible to evaluate the beneficial effects of Satsuma mandarin by measuring the serum $\beta$-CRX level, which can be a useful biomarker that reflects the intake frequency of Satsuma mandarin with accuracy. In the epidemiological study, to clarify whether Satsuma mandarin intake is effective in the prevention of several diseases, we think that survey must be undertaken in the area where Satsuma mandarin is considerably more popular than in the rest of Japan. Satsuma mandarin is the most frequently consumed domestic fruit in Japan. However, the consumption of this fruit has decreased or remained at the same level (26). It is impossible to find out the beneficial effects of Satsuma mandarin intake if the survey is conducted in an area where residents eat little of the Satsuma mandarin, such as, for example, urban areas, where the Satsuma mandarin is not harvested. From these reasons, we examined the seasonal change in the serum $\beta$ CRX level using volunteers who are residents in an area where residents eat largely Satsuma mandarin compared with the rest of Japan.

In this study, we evaluated the seasonal changes in the serum $\beta$-CRX level and investigated the predictors of serum $\beta$-CRX level by multiple linear regression anal- 
ysis. The results show that the serum $\beta$-CRX level changes dramatically as the intake frequency of Satsuma mandarin increases and that the intake volume of Satsuma mandarin, sex, age, month of blood sampling, body mass index, alcohol intake and smoking habit are predictors of serum $\beta$-CRX levels.

Positive correlations between the serum $\beta$-CRX level and age were observed in both males and females (Table 2 ). These were due to the results of the positive correlation between intake volume of Satsuma mandarin and age. As shown in Table 2, although a statistically significant correlation between the serum $\beta$-CRX level and body mass index was not observed in either males or females, we found that body mass index was a negative predictor of the serum $\beta$-CRX level, especially among females (Table 3). These findings were consistent with previous results concerning the relationship between serum $\beta$-carotene levels and body mass index $(27,28)$. Carotenoids are distributed in serum and adipose tissue, adipose tissue being the dominant storage tissue (29). Therefore, it is conceivable that, in a person with a high fat mass index, a larger proportion of ingested $\beta$-CRX would be absorbed by fat tissue than in the case of a lean person if all other metabolic factors were equal.

A negative correlation between the serum $\beta$-CRX level and alcohol intake was observed among males (Table 2). This was also due to the result of a negative correlation between the intake volume of Satsuma mandarin and alcohol. It has been reported that alcohol stimulates the induction of the transforming reaction from pro-vitamin A to retinol through the activation of lipid metabolism $(30,31)$. In addition, in our study, alcohol intake was a statistically significant predictor of serum $\beta$-CRX levels in males (Table 3). On the other hand, previous epidemiologic studies demonstrated that active smokers have a lower level of serum carotenoids and tocopherols than non-smokers $(28,32$, 33). Cigarette smoke contains many oxidants and free radicals (34). In our survey, smoking habit was a statistically significant predictor of serum $\beta$-CRX levels, especially among males (Table 3 ). In contrast, although smoking habit was correlated negatively with serum $\beta$ CRX in females (Table 2), this variable was not significant predictor of serum $\beta$-CRX (Table 3). These were due to the result of skewed distribution of smoking habit because there were only two female ex-smokers (Table 1).

Recent epidemiological studies have shown that the serum concentration of carotenoids or vitamins is well correlated with the intake of fruits and vegetables (712). Numerous case-control or prospective cohort studies have shown the relationship of the intake of fruits and vegetables with chronic diseases, such as cancer or cardiovascular disease, by using biomarkers ( $\beta$-carotene, lycopene, ascorbic acid, and $\alpha$-tocopherol) that reflect the intake frequency of fruits and vegetables (1320). However, the above biomarkers cannot be used to estimate the intake volume of specific foods because carotenoids and vitamins are abundant in fruits and vegetables (21-24). On the other hand, in our study, serum
$\beta$-CRX levels increased markedly according to increases in the frequency of Satsuma mandarin intake (Fig. 1). Although apricot, chili, loquat, papaya, peach, pepper, persimmon and tangerine contain $\beta$-CRX $(21-24)$, they are not as large a source of $\beta$-CRX as Satsuma mandarin. In our survey, except for Satsuma mandarin, the frequency of consumption of fruits and vegetables and related processed food, including juice or canned foods that contain $\beta$-CRX, were not statistically significant predictors. Because one Satsuma mandarin (about $100 \mathrm{~g}$ ) includes $1-2 \mathrm{mg}$ of $\beta$-CRX in the juice sacs and no other fruits or vegetables contain such large quantities of $\beta$-CRX (24), we assume that the main source of $\beta$-CRX for the Japanese is Satsuma mandarin. Actually, in our survey, Satsuma mandarin was the only predictor of serum $\beta$-CRX obtained from foods (Table 3 ).

The intake volume of Satsuma mandarin increased in November (Fig. 1). In male participants, the intake of Satsuma mandarin was the largest in November and decreased in January. Among the female participants, there was no difference in the intake data of Satsuma mandarin between November and January. However, the serum concentration of $\beta$-CRX increased until January in males and females (Fig. 1). Furthermore, although most participants did not eat Satsuma mandarin in May and July, no immediate decrease in serum $\beta$-CRX was observed. The decrease in serum $\beta$-CRX was gradual (Fig. 1). These results indicate that $\beta$-CRX accumulate easily in adipose tissues and is gradually released to the blood circulation. Numerous studies on the absorption, metabolism, and distribution of carotenoids, such as $\beta$-carotene and lycopene, in several tissues have been reported (35-38); however, little is known regarding the biokinetics of xanthophylls, such as $\beta$-CRX. Xanthophylls, such as $\beta$-CRX, have a hydroxyl residue that exists as a xanthophyll ester with fatty acids in fruits or vegetables $(23,39)$. When a xanthophyll ester is absorbed by the intestine, it is cleaved by an endogenous enzyme to free xanthophylls (39). In addition, it is known that the blood concentration of $\beta$ $\mathrm{CRX}$, in contrast to that of $\beta$-carotene or lycopene, is high even when the consumption of the substance is low $(40,41)$. For this reason, we assume that absorbed xanthophylls from the intestines accumulate easily in adipose tissue as xanthophyll esters form with fatty acids. Recently, it was reported that xanthophyll esters are present in human skin and that these esters in human skin may be formed by reesterification of xanthophylls following absorption (39). From these facts, it can be concluded that xanthophylls are easily absorbed and accumulate in greater amounts than other carotenoids, such as $\beta$-carotene. Therefore, it is conceivable that the serum concentration of $\beta$-CRX increased dramatically with the intake of Satsuma mandarin and maintained a high level for several months even though participants had not eaten food considered to be a source of $\beta$-CRX, such as citrus fruits, or related processed foods, including juice and canned foods. Actually, in our survey, Satsuma mandarin intake 2 mo prior is also a statistically significant predictor of serum $\beta$ - 
CRX levels (Table 3). This result strongly supports that accumulated $\beta$-CRX is gradually released to the blood circulation extending for at least 2 mo.

In this study, we developed multiple linear regression models and found the predictors of serum $\beta$-CRX. Two aspects of these findings are interesting. First, in our survey, Satsuma mandarin is the only predictor of serum $\beta$-CRX levels among Japanese foods. Second, the serum $\beta$-CRX levels are useful biomarkers for estimating the frequency of intake of Satsuma mandarin. These findings make it possible to evaluate the beneficial effects of Satsuma mandarin using serum $\beta$-CRX levels in epidemiological studies. From the results of multiplelinear regression analysis, serum $\beta$-CRX levels $(Y)$ could be calculated using the following formula;

$$
\begin{aligned}
Y_{1}(\mu \mathrm{g} / \mathrm{dL})= & -201.023+2.444 X_{1}+1.551 X_{2} \\
& +17.752 X_{3}+35.422 X_{4}+2.897 X_{5} \\
& -11.497 X_{6}-5.729 X_{7} \\
Y_{2}(\mu \mathrm{g} / \mathrm{dL})= & -159.485+1.879 X_{1}+1.028 X_{2} \\
& +14.919 X_{3}+3.401 X_{5}-11.852 X_{6} \\
& -9.585 X_{7} \\
Y_{3}(\mu \mathrm{g} / \mathrm{dL})= & -22.321+5.353 X_{1}+3.593 X_{2} \\
& +17.428 X_{3}+2.023 X_{5}-4.984 X_{8}
\end{aligned}
$$

$Y_{1}$ : serum $\beta$-CRX level in Model for both sexes, $Y_{2}$ : serum $\beta$-CRX level in Male model, $Y_{3}$ : serum $\beta$-CRX level in Female model, $X_{1}$ : Satsuma mandarin intake at the month of blood sampling (pieces/d), $X_{2}$ : Satsuma mandarin intake two months ago (pieces/d), $X_{3}$ : month of blood sampling (score; $\left.1-5\right), X_{4}$ : Sex (male; 1 , female; 2 ), $X_{5}$ : age (y), $X_{6}$ : smoking habit (score; $1-5), X_{7}$ : alcohol habit (score; $\left.1-5\right), X_{8}$ : body mass index $\left(\mathrm{kg} / \mathrm{m}^{2}\right)$

These formulas also provide the possibility to estimate the frequency of Satsuma mandarin consumption before 2 mo prior using serum $\beta$-CRX data.

Furthermore, the serum $\beta$-CRX levels in our survey were extremely high compared with those reported elsewhere $(9,40-43)$. Wahlqvist et al. reported that, in Australia, the intake of $\beta$-CRX from daily food is about $0.2 \mathrm{mg}$ and the serum concentration of $\beta$-CRX is 10.6 to $15.5 \mu \mathrm{g} / \mathrm{dL}(40)$. Michaud et al. reported that, in the United States, the intake of $\beta$-CRX from daily food is about $0.07 \mathrm{mg}$ and the serum concentration of $\beta$-CRX is 12.3 to $13.3 \mu \mathrm{g} / \mathrm{dL}$ (9). To compare these previous epidemiological results with the present study, we estimated that the daily intake of $\beta$-CRX in participants who ate one to three Satsuma mandarins daily in our survey was about 1 to $6 \mathrm{mg}$ or more. Because of this large $\beta$-CRX intake from Satsuma mandarin, the serum $\beta$-CRX levels were much higher in the present study than in others.

\section{Acknowledgment}

This study was supported in part by a grant from the Ministry of Agriculture, Forestry, and Fishers (MAFF) for a food research project titled "Integrated Research on Safety and Physiological Function of Food" and with special coordination funds from the Ministry of Education, Culture, Sports, Science and Technology, Japan. The authors thank all of the participants who volun- teered for the study. The authors also thank Mrs. Horiike H., Mrs. Kawasaki A., and Ms. Fukazawa Y. for technical assistance in the analysis of the blood samples and the dietary data.

\section{REFERENCES}

1) Jenkins DJ, Popovich DG, Kendall CW, Vidgen E, Tariq N, Ransom TP, Wolever TM, Vuksan V, Mehling CC, Boctor DL, Bolognesi C, Huang J, Patten R. 1997. Effect of a diet high in vegetables, fruit, and nuts on serum lipids. Metabolism 46: 530-537.

2) Kurowska EM, Spence JD, Jordan J, Wetmore S, Freeman DJ, Piche LA, Serratore P. 2000. HDL-cholesterol-raising effect of orange juice in subjects with hypercholesterolemia. Am J Clin Nutr 72: 1095-1100.

3) Feldman EB. 2001. Fruits and vegetables and risk of stroke. Nutr Rev 59: 24-27.

4) Ford ES, Mokdad AH. 2001. Fruit and vegetable consumption and diabetes mellitus incidence among U.S. adults. Prev Med 32: 33-39.

5) Hooper L. 2001. Dietetic guidelines: diet in secondary prevention of cardiovascular disease. J Hum Nutr Diet 14: $297-305$.

6) Terry P, Terry JB, Wolk A. 2001. Fruit and vegetable consumption in the prevention of cancer: an update. $J$ Intern Med 250: 280-290.

7) Campbell DR, Gross MD, Martini MC, Grandits GA, Stavin JL, Potter JD. 1994. Plasma carotenoids as biomarkers of vegetable and fruit intake. Cancer Epidemiol Biomarkers Prev 3: 493-500.

8) Drewnowski A, Rock CL, Henderson SA, Shore AB, Fischler C, Galan P, Preziosi P. 1997. Serum $\beta$-carotene and vitamin $\mathrm{C}$ as biomarkers of vegetable and fruit intakes in a community-based sample of French adults. Am J Clin Nutr 65: 1796-1802.

9) Michaud DS, Giovannucci EL, Ascherio A, Rimm EB, Forman MR, Sampson L, Willett WC. 1998. Associations of plasma carotenoid concentrations and dietary intake of specific carotenoids in samples of two prospective cohort studies using a new carotenoid database. Cancer Epidemiol Biomarker Prev 7: 283-290.

10) Tucker KL, Chen H, Vogel S, Wilson PW, Schaefer EJ, Lammi-Keefe CJ. 1999. Carotenoid intakes, assessed by dietary questionnaire, are associated with plasma carotenoid concentrations in an elderly population. J Nutr 129: 438-445.

11) van Kappel AL, Steghens JP, Zeleniuch-Jacquotte A, Chajes V, Toniolo P, Riboli E. 2001. Serum carotenoids as biomarkers of fruit and vegetable consumption in the New York Women's Health Study. Public Health Nutr 4: 829-835.

12) Papas A, Stacewicz-Sapuntzakis M, Lagiou P, Bamia C, Chloptsios Y, Trichopoulou A. 2003. Plasma retinol and tocopherol levels in relation to demographic, lifestyle and nutritional factors of plant origin in Greece. $\mathrm{Br} J$ Nutr 89: 83-87.

13) Stahelin HB, Gey KF, Eichholzer M, Ludin E, Bernasconi F, Thurneysen J, Brubacher G. 1991. Plasma antioxidant vitamins and subsequent cancer mortality in the 12-year follow-up of the prospective Basel Study. Am J Epidemiol 133: 766-775.

14) Gey KF. 1993. Prospects for the prevention of free radical disease, regarding cancer and cardiovascular disease. Br Med Bull 49: 679-699.

15) Omenn GS, Goodman GE, Thornquist MD, Balmes J, 
Cullen MR, Glass A, Keogh JP, Meyskens FL. Jr, Valanis B, Williams JH. Jr, Barnhart S, Cherniack MG, Brodkin CA, Hammar S. 1996. Risk factors for lung cancer and for intervention effects in CARET, the Beta-Carotene and Retinol Efficacy Trial. J Natl Cancer Inst 88: 15501559.

16) Comstock GW, Alberg AJ, Huang HY, Wu K, Burke AE, Hoffman SC, Norkus EP, Gross M, Cutler RG, Morris JS, Spate VL, Helzlsouer KJ. 1997. The risk developing lung cancer associated with antioxidants in the blood: ascorbic acid, carotenoids, $\alpha$-tocopherol, selenium, and total peroxyl radical absorbing capacity. Cancer Epidemiol Biomarkers Prev 6: 907-916.

17) Woodson K, Tangrea JA, Barrett MJ, Virtamo J, Taylor PR, Albanes D. 1999. Serum $\alpha$-tocopherol and subsequent risk of cancer among male smokers. J Natl Cancer Inst 91: 1738-1743.

18) Smith-Warner SA, Elmer PJ, Tharp TM, Fosdick L, Randall B, Gross M, Wood J, Potter JD. 2000. Increasing vegetable and fruit intake: Randomized intervention and monitoring in an at-risk population. Cancer Epidemiol Biomarker Prev 9: 307-317.

19) Schiff MA, Patterson RE, Baumgartner RN, Masuk M, van Asselt-King L, Wheeler CM, Becker TM. 2001. Serum carotenoids and risk of cervical intraepithelial neoplasia in Southwestern American Indian women. Cancer Epidemiol Biomarker Prev 10: 1219-1222.

20) Holick CN, Michaud DS, Stolzenberg-Solomon R, Mayne ST, Pietinen P, Taylor PR, Virtamo J, Albanes D. 2002. Dietary carotenoids, serum beta-carotene, and retinol and risk of lung cancer in the alpha-tocopherol, betacarotene cohort study. Am J Epidemiol 156: 536-547.

21) Mangels AR, Holden JM, Beecher GR, Forman MR, Lanza E. 1993. Carotenoid content of fruits and vegetables: An evaluation of analytic data. J Am Diet Assoc 93: 284-296.

22) Holden JM, Eldrige AL, Beecher GR, Buzzard MI, Bhagwat S, Davis CS, Douglass LW, Gebhardt S, Haytowitz D, Schakel S. 1999. Carotenoid content of U. S. foods: An update of the database. J Food Comp Anal 12: 169-196.

23) Dietmar EB, Ameneh B. 2001. Carotenoid esters in vegetables and fruits: A screening with emphasis on $\beta$ Cryptoxanthin esters. J Agric Food Chem 49: 2064 2070.

24) Goodner KL, Rouseff RL, Hofsommer HJ. 2001. Orange, mandarin, and hybrid classification using multivariate statistics based on carotenoid profiles. J Agric Food Chem 49: 1146-1150.

25) Sugiura $M$, Kato $M$, Matsumoto $H$, Nagao A, Yano $M$. 2002. Serum concentration of $\beta$-cryptoxanthin in Japan reflects the frequency of Satsuma mandarin (Citrus unshiu Marc.) consumption. J Health Sci 48: 350353.

26) Statistics Bureau \& Statistics Center of the Ministry of Public Management, Home Affairs, Post and Telecommunications (2002) Family income and expenditure survey report.

27) Drewnowski A, Rock CL, Henderson SA, Shore AB, Fischler C, Galan P, Preziosi P, Hercberg S. 1997. Serum $\beta$ carotene and vitamin $C$ as biomarkers of vegetable and fruit intakes in a community-based sample of French adults. Am J Clin Nutr 65: 1796-1802.

28) Wallstrom P, Wirfalt E, Lahmann PH, Gullberg B, Janzon L, Berglund G. 2001. Serum concentrations of $\beta$ carotene and $\alpha$-tocopherol are associated with diet, smoking, and general and central adiposity. Am J Clin Nutr 73: 777-785.

29) van Vliet T. 1996. Absorption of beta-carotene and other carotenoids in human and animal models. Eur J Clin Nutr 50: S32-S37.

30) Baraona E, Lieber CS. 1979. Effects of ethanol on lipid metabolism. J Lipid Res 20: 289-315.

31) Taskinen MR, Valimaki M, Nikkila EA, Kuusi T, Ehnholm C, Ylikahri R. 1982. High density lipoprotein subfractions and post-heparin plasma lipases in alcoholic men before and after ethanol withdrawal. Metabolism 31: 1168-1174.

32) Stryker WS, Kaplan LA, Stein EA, Stampfer MJ, Sober A, Willett WC. 1988. The relation of diet, cigarette smoking, alcohol consumption to plasma $\beta$-carotene and $\alpha$ tocopherol levels. Am J Epidemiol 127: 283-296.

33) Ito Y, Sasaki R, Suzuki S, Aoki K. 1991. Relationship between serum xanthophylls levels and the consumption of cigarettes, alcohol or foods in healthy inhabitants of Japan. Int J Epidemiol 20: 615-620.

34) Church DF, Pryor WA. 1985. Free-radical chemistry of cigarette smoke and its toxicological implications. Environ Health Perspect 64: 111-126.

35) Kaplan LA, Lau JM, Stein EA. 1990. Carotenoid composition, concentrations, and relationships in various human organs. Clin Physiol Biochem 8: 1-10.

36) Cooney RV, Bertram JS, Hankin JH, Kolonel LN, Miyake A, Billings K, Bourne W. 1991. Relationship between dietary, serum, and tissue levels of carotenoids. Cancer Lett 61: 81-87.

37) Nair PP, Lohani A, Norkus EP, Feagins H, Bhagavan HN. 1996. Uptake and distribution of carotenoids, retinal, and tocopherols in human colonic epithelial cells in vivo. Cancer Epidemiol Biomarker Prev 5: 913-916.

38) Glise D, Riondel J, Favier A. 1998. Comparative distribution of $\beta$-carotene and lycopene after intraperitoneal administration in mice. In Vivo 12: 447-454.

39) Wingerath T, Stahl W, Sies H. 1995. $\beta$-Cryptoxanthin selectively increases in human chylomicrons upon ingestion of tangerine concentrate rich in beta-cryptoxanthin esters. Arch Biochem Biophys 324: 385-390.

40) Wahlqvist ML, Wattanapenpaiboon N, Macrae FA, Lambert JR, MacLennan R, Hsu-Hage BH. 1994. Changes in serum carotenoids in subjects with colorectal adenomas after 24 mo of $\beta$-carotene supplementation. Australian polyp prevention project investigators. Am J Clin Nutr 60: $936-943$.

41) Albanes D, Virtamo J, Taylor PR, Rautalahti M, Pietinen P, Heinonen OP. 1997. Effects of supplemental $\beta$-carotene, cigarette smoking, and alcohol consumption on serum carotenoids in the Alpha-Tocopherol, Beta-Carotene Cancer Prevention Study. Am J Clin Nutr 66: 366 372.

42) Fotouhi N, Meydani M, Santos MS, Meydani SN, Hennekens CH, Gaziano JM. 1996. Carotenoid and tocopherol concentrations in plasma, peripheral blood mononuclear cells, and red blood cells after long-term $\beta$-carotene supplementation in men. Am J Clin Nutr 63: 553-558.

43) Nierenberg DW, Dain BJ, Mott LA, Baron JA, Greenberg ER. 1997. Effects of $4 \mathrm{y}$ of oral supplementation with $\beta$ carotene on serum concentrations of retinol, tocopherol, and five carotenoids. Am J Clin Nutr 66: 315319. 